\title{
FERNANDO DE ALMEIDA (d. 1660): TRADITION AND INNOVATION IN MID-SEVENTEENTH-CENTURY PORTUGUESE SACRED MUSIC ${ }^{*}$
}

\author{
FERNANDO DE ALMEIDA (†1660): TRADICIÓN E INNOVACIÓN \\ EN LA MÚSICA SACRA PORTUGUESA DE MEDIADOS DEL SIGLO XVII
}

\author{
João Vaz \\ CESEM - Universidade Nova de Lisboa \\ Escola Superior de Música de Lisboa - Instituto Politécnico de Lisboa \\ $\&$ \\ João Pedro d'Alvarenga \\ CESEM - Universidade Nova de Lisboa
}

\begin{abstract}
The Library of the Ducal Palace at Vila Viçosa preserves three large choirbooks of polyphonic repertoire intended for Holy Week, prepared between 1735 and 1736 by a copyist of the Patriarchal Church. These choirbooks contain all the known extant works by Fernando de Almeida (died in 1660). When comparing the music of Fernando de Almeida with that of his near contemporary João Lourenço Rebelo (1610-1661), the different trends in Portuguese early- to mid-seventeenth-century church music become clear, especially if viewed in the light of the acknowledged aesthetic and compositional premises explained in the 1649 Defensa de la mvsica moderna by King João IV. Rebelo's concertato works incline towards the style of north-Italian composers. The ingenuity of Fernando de Almeida's style, which is particularly noticeable in his eight-voice Holy Week responsories, lays in the integration of prominent Baroque features within the mould of Iberian Mannerist tradition.
\end{abstract}

\section{Key words}

Life and works of Fernando de Almeida; Concertato and polychoral music in Portugal; Aesthetic and compositional premises in 17th-century Portuguese music; João Lourenço Rebelo; King João IV; Polyphonic responsories; Baroque features in Iberian Mannerist music.

\section{Resumen}

La Biblioteca del Palacio Ducal de Vila Viçosa posee tres grandes libros de coro con repertorio polifónico destinado a la Semana Santa, preparados entre 1735 y 1736 por un copista de la Iglesia Patriarcal. Estos libros de coro contienen todas las obras de Fernando de Almeida (m. 1660) que hayan sobrevivido hasta los días de hoy. La comparación de la música de Fernando de Almeida con la de su cási contemporáneo João Lourenço Rebelo (1610-1661) evidencia las distintas orientaciones en la música sacra portuguesa de principios a mediados del siglo XVII, especialmente cuando observadas bajo las premisas estéticas y composicionales explanadas en la Defensa de la mvsica moderna (1649) del Rey D. João IV. El estilo concertato de Rebelo se acerca de los compositores del Norte de Italia. La inventiva del estilo de Fernando de Almeida, particularmente notable en sus Responsorios a ocho voces para la Semana Santa, incorpora prominentes características barrocas en el molde de la tradición manierista ibérica.

\section{Palabras clave}

Vida y obras de Fernando de Almeida; Música concertada y policoral en Portugal; Premisas estéticas y composicionales en la música portuguesa del siglo XVII; João Lourenço Rebelo; El Rey Dom João IV; Responsorios polifónicos; Rasgos barrocos en la música del manierismo ibérico.

* An early version of this article was read at the 15th Biennial International Conference on Baroque Music, University of Southampton, UK, July 2012. The authors acknowledge the assistance of the CESEM (Centre for the Study of Sociology and Aesthetics of Music) at the Universidade Nova de Lisboa, and the FCT (Portuguese Foundation for Science and Technology). 
Until quite recently, only a few vague biographical details on Fernando de Almeida were known from the Bibliotheca Lusitana, written by the Jesuit Francisco da Cruz in the late 1680s and revised at the end of the following decade (after which it remained in manuscript), and from the second volume of Bibliotheca Lusitana by Diogo Barbosa Machado, printed in 1743. Almeida was born in Lisbon, was possibly a student of Duarte Lobo (who was chapel master of Lisbon Cathedral from about 1591 until at least 1639), and took the habit of the military Order of Christ at the Royal Convent of Tomar; he was elected visitor of the Order in 1656 and died on March 21, 1660. ${ }^{1}$ A recent master thesis uncovered some additional details: Almeida took part on the general chapters of his Order in 1644 and 1653, on the latter date in the quality of "definitor and deputy"; in 1649 he had moved back to Lisbon on the orders of King João IV. It is however the records of the Inquisition that cast light on the life and horrible death of Fernando de Almeida. ${ }^{3}$ On March 12, 1659 , when staying at the Convent of Nossa Senhora da Luz in Lisbon, Almeida was arrested on the charge of perjury against the Prior of the Convent in Tomar, whom he had accused of sodomy. Subject to an inquiry, he declared on March 28 of that year that he was 55 years old (having thus been born in 1603 or 1604); that he was the son of António Jorge, a tailor, who was born in the vicinity of Bragança, and Maria Lopes, who was born in Lisbon; that he could not remember the names of his paternal grandparents and that his maternal grandparents were named Manuel Gonçalves and Isabel Gago, both native of Lisbon; that he had been baptized in the Church of Santa Justa in Lisbon, having received the chrism in that same church; that he knew how to read and write, having studied Latin, morals and music; and that he was a religious for 40 years (having thus joined the Order of Christ in 1618 or 16194); apparently, he never held any official musical position. ${ }^{5}$ Being found guilty, he was sentenced to prison including fasting on bread and water, loss of active and passive voice, permanent reduction to the lay state and payment of judicial costs. He performed public penance in an auto-de-fé on October 26, 1659 and died in the Convent of Tomar shortly

1 CRUZ, Francisco da, Bibliotheca Lusitana, P-La, Ms. 51-V50: 135 and 170; MACHADO, 1743: 16; see the modern edition in NERY (ed.), 1984: 45-46.

2 COTA, 2007, vol. 1: 172-173, and vol. 2: 37.

3 Process against Fernando de Almeida, P-Lant, Tribunal do Santo Ofício, Inquisição de Lisboa, Proc. 11047, available at < digitarq. arquivos.pt/details?id=2311228> (accessed February 10, 2015). The process was recently located by Cristina Cota, to whom we thank for calling our attention to this source.

4 MACHADO, 1743: 16, gives 1638 as the year Fernando de Almeida entered the convent in Tomar.

5 Although Francisco da Cruz says he was " $\mathrm{M}^{\mathrm{e}}$ da Capp" do Conu $^{\text {to }}$ de Thomar" (chapel master of the Convent of Tomar); see CRUZ, Bibliotheca Lusitana: 170. before April $26,1660^{6}$ in appalling circumstances, in a damp dungeon located directly under a cattle house, hungry, naked, covered with sores and lice and with no sacraments; his shackles were removed only after he had died and his corpse was simply thrown into a common grave with no proper rituals.

Much of Fernando de Almeida's music seem to have had the same fate as its composer. For instance, in the first part of the Index of the library of music of King João IV there is an entry for a twelve-voice mass "in the third tone" by Fernando de Almeida, ${ }^{7}$ which was lost in the great Lisbon earthquake of 1755 , along with the massive collection of music begun in the middle of the sixteenth century by João IV's great-grandfather, Teodósio I, fifth Duke of Braganza (died in 1563). More fortunate was Fernando de Almeida's Livro da Somana Santa (Book for Holy Week) which, so Francisco da Cruz tells us, "m(ui)to estimaua El Rey D. João o 4. ${ }^{\circ}$ [e que] a morte atalhou [de] emprimir od(i)to liuvro, e outros muntos q(ue) se conseruão em Thomar". ${ }^{8}$ According to Barbosa Machado, it was this manuscript book, made up of "Lamentaçoens, Responsorios, $e$ Misereres dos Tres Officios da Quarta, Quinta, e Sesta feira da Semana Santa" (Lamentations, Responsories and Misereres for the three Offices of Wednesday, Thursday and Friday of Holy Week), that King João V, on April 1714, ordered to be copied "quando assistio no Convento de Thomar para que se cantasse na sua Capella Real". ${ }^{9}$ From this copy, which existed at the royal library of music, the contents were entered in liturgical order into three large choirbooks of polyphonic repertory intended for Holy Week, which were prepared between 1735 and 1736 by a copyist associated with the Patriarchal Church, a certain Vicente Perez Petroch Valentino, for use of the Royal Chapel at the Ducal Palace in Vila Viçosa (see Figure 1). ${ }^{10}$ These late choirbooks contain all the known extant music by Fernando de Almeida: sixteen works, making up a total of forty pieces, as shown on Table 1.

6 As seen just above, Francisco da Cruz (repeated in Barbosa Machado) gives March 21, 1660 as the date Fernando de Almeida died; see CRUZ, Bibliotheca Lusitana: 135.

7 Primeira parte do Index, 1649: 452. On the Royal Library of Music and its printed index see NERY, 1990.

8 "King João IV greatly admired and whose death prevented from printing the said book, along with many others that are kept in Tomar"; CRUZ, Bibliotheca Lusitana: 135.

9 "when he visited the Convent of Tomar, so that he could have it sung in his Royal Chapel"; MACHADO, 1743: 16.

$10 P-V V$ J.12/A.6, dated 1735; $P$ - $V V$ J.15/A.9 and J.16/A.10, both dated 1736 (henceforth Ms A, Ms B1 and Ms B2, respectively). On these choirbooks, see ALVARENGA, 8/2 (Cambridge, 2011): 179214, especially at 184-188, and the inventories at 199-205; see also ALVARENGA, 9/2 (Cambridge, 2012). It should be noted that Portuguese kings since 1640 were also Dukes of Braganza, the main estate and residence of the dukedom being in Vila Viçosa, in the northeast of the Alentejo province, near the Spanish border. 
TABLE 1. The extant works of Fernando de Almeida ${ }^{11}$

\begin{tabular}{|c|l|l|}
\hline 1 & Ferial Mass (K S A), 4 vv & Ms A, fols. 23v-26r+32v-36r [8] \\
\hline 2 & Mass for Palm Sunday (K C S A), 6/4 vv & Ms B1, fols. 14v-27r+30v-35r [6] \\
\hline 3 & Gloria, laus, et honor, 6 vv (refrain only) & Ms B1, fols. 9v-14r [5] \\
\hline 4 & Benedictus Dominus Deus Israel (i), 4 vv & Ms A, fols. 85v-88r [28] \\
\hline 5 & Benedictus Dominus Deus Israel (ii), 8/4 vv & Ms B1, fols. 97v-103r [24]; Ms B2, fols. 36v-42r [11] \\
\hline 6 & Miserere mei Deus, Ps 50 (i), 4 vv & Ms A, fols. 88v-92r [29] \\
\hline 7 & Miserere mei Deus, Ps 50 (ii), 4 vv & Ms A, fols. 137v-142r [43] \\
\hline 8 & Miserere mei Deus, Ps 50 (iii), 8/4 vv & Ms B1, fols. 103v-116r [25] \\
\hline 9 & Miserere mei Deus, Ps 50 (iv), 8/4 vv & Ms B2, fols. 42v-53r [12] \\
\hline 10 & Lamentation I for Maundy Thursday (i), 4 vv & Ms A, fols. 63v-69r [18] \\
\hline 11 & Lamentation I for Maundy Thursday (ii), 8vv & Ms B1, fols. 63v-73r [14] \\
\hline 12 & Lamentation I for Good Friday, 8 vv & Ms B2, fols. [i]v-9r [1] \\
\hline 13 & Lamentation I for Holy Saturday, 8 vv & Ms B2, fols. 66v-77r [14] \\
\hline $14-22$ & Responsories I-IX for Maundy Thursday, 8/4 vv & Ms B1, fols. 73v-97r [15-23] \\
\hline $23-31$ & Responsories I-IX for Good Friday, 8/4 vv & Ms B2, fols. 9v-36r [2-10] \\
\hline $32-40$ & Responsories I-IX for Holy Saturday, 8/4 vv & Ms B2, fols. 77v-97r [15-23] \\
\hline
\end{tabular}

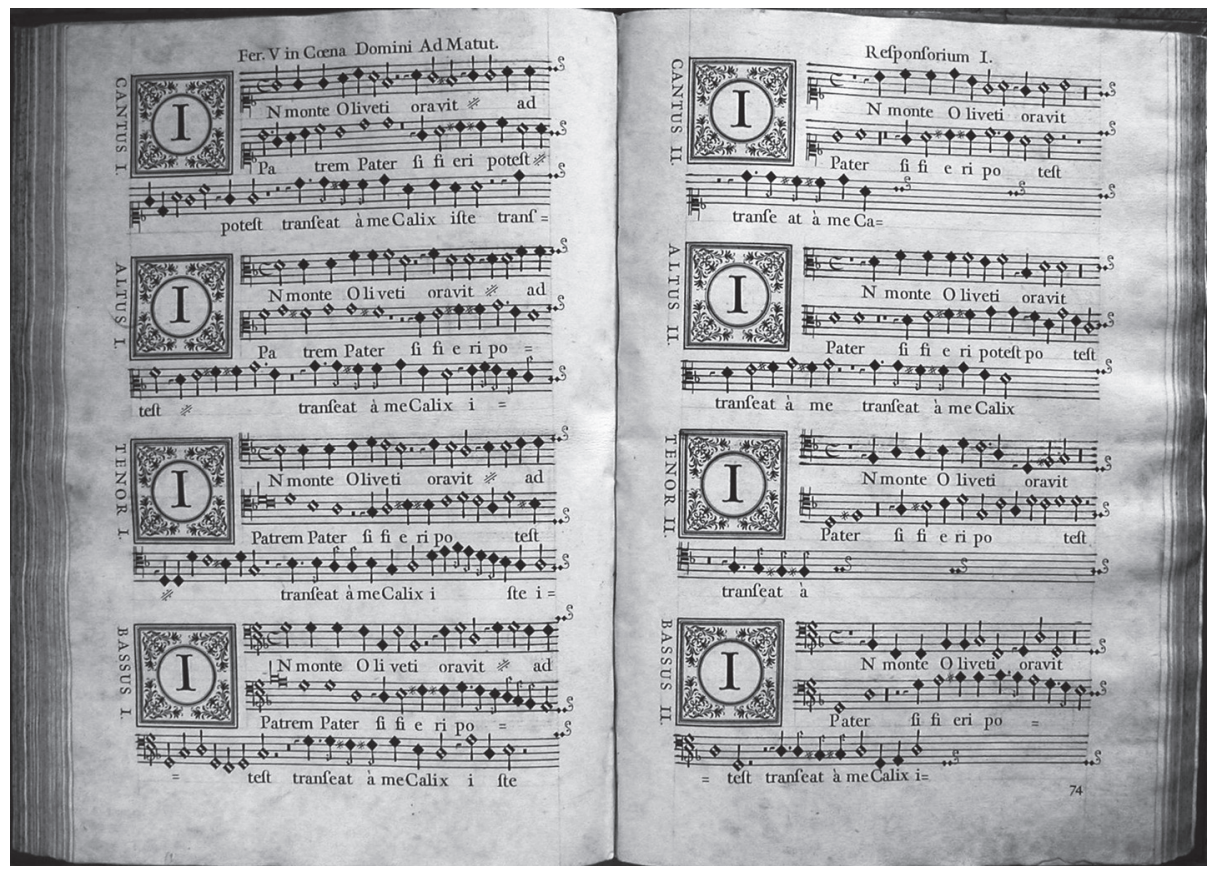

Figure 1.P-VV J.15/A.9 (Ms B1, dated 1736), fols. 73v-74r: Fernando de Almeida, Responsory I for Maundy Thursday, opening

11 Nos. 4 and 5 are even-verse settings; nos. 6 to 9 are odd-verse settings plus the second part of the last, even verse. Numbers in square brackets in the rightmost column refer to the inventories of the manuscripts in ALVARENGA, 8/2 (Cambridge, 2011): 199-205. 
In accordance with the taste of the 1720s and early 1730s, heavily influenced by Roman models, and with the requirements of the Ceremonial of the pontifical chapels, adopted by the Patriarchal Church of Lisbon probably in 1718, the hymn Gloria, laus and the four settings of the Lamentations have additional verses composed by Manuel Soares, organist of the Royal Chapel (died in 1756), and Girolamo Bezzi, a castrato hired in 1719 for the Patriarchal Church. The style of these additions imitates the original, with the purpose of providing polyphony for the complete texts, as they appear in the Roman Missal revised in 1604 by order of Pope Clement VII (the refrain of the Gloria, laus and its first five strophes out of the ten that appeared in the 1570 Missale Romanum) and in the Breviary of Pius V (the Lamentations, but with one verse less in each lesson, as became usual in most post-Tridentine liturgical sources). ${ }^{12}$

Fernando de Almeida's extant works should be firstly assessed in the light of the acknowledged aesthetic premises for sacred music in early- to mid-seventeenth-century Portugal. These are clearly explained and exemplified in the 1649 brief treatise Defensa de la mvsica moderna by King João IV. ${ }^{13}$ In short, the musical work is understood as having a textual quality, not only in the sense that it forms a discourse in itself, but also because verbal structures constitute the model to which the musical structures must submit and adapt, the specific interpretative relationship between music and text being determined for each individual situation and syntagmatic unit according to various concerns at different levels, being them syntactic, declamatory, expressive, mimetic, or even symbolic. Text thus imposes a significant redundancy on musical gesture. This aims at moving the listener's affections and its effectiveness, depending on the level of competence of the listener, is a consequence of either the proprietas of music writing itself (that is, the choice of mode or tonality, the progression of consonances and modulation, the exploring of high and low registers, and the use of quick or slower note values in accordance with the text), or the use of musical-rhetorical figures expressing analogy, emphasis or amplification. As detailed by the king in his treatise (with the mentioning of various examples which we omit for the sake of brevity):

De dos modos acostumbran los buenos compositores acomodar la musica a la letra; vnos para mouer a lo que dize la letra [...] Otros acomodan la musica a la letra para mostrar habilidad: [...] Iuan Lorẽço Rabello en el Psalmo

12 See ALVARENGA, 8/2 (Cambridge, 2011): 185-186. 13 See ALVARENGA, 2009: 239-250.
Qui habitat donde dize non timebis à timore nocturno, y en el Fratres sobrij estote de las Completas donde dize circuit; [...] efficaces unos para quien entiende la letra, otros para quien entiende la musica, y la letra. ${ }^{14}$

Reference to music by João Lourenço Rebelo (16101661) as an example of use of musical-rhetorical devices is indeed revealing of an exceptional, although not unique circumstance, because Rebelo's music, especially in his large-scale pieces, has in general an abstract architectural quality, more inclined to ignore the text than to underline it, with effects at times of massive sound, while at others transparent, that are combined in a diversified interplay of often asymmetrical groupings that bring together voices and instruments, challenging in its instrumental writing and vocal ornamentation. This inclines towards the early seventeenth-century concertato style of northern Italy, to which repertories Rebelo, as a protégé of the king, should have had access in the volumes kept in the royal library. His music is nevertheless not lacking in contrapuntal refinement, characteristic of late-sixteenth- and seventeenth-century Portuguese composers. ${ }^{15}$

Rebelo's thirteen-voice setting of the Magnificat odd-verses, dated 1639, is exemplary of his large-scale concertato pieces (see Table 2), the same way his undated three-voice setting of the first Lamentation for Holy Saturday (SAT and $b c$ ) is an example of highly demanding small-scale concertato music; also his even-verse setting of the psalm Laudate pueri for one treble voice, six instruments and $b c$, dated 1640, although not an ostinato piece, but because of the recurring psalm tone formula, certainly echoes the "Sonata sopra Sancta Maria" in Monteverdi's 1610 Vespro della Beata Vergine and a small number of similar pieces in early-seventeenth-century prints by north-Italian composers. ${ }^{16}$

14 "There are two ways in which good composers tend to adapt the music to the text; some do it to make one feel what the words say [...] Others adapt the music to the text to show their skill: [...] as João Lourenço Rebelo in the Psalm Qui habitat, when it says non timebis a timore nocturno and in the Fratres sobrii estote for Compline when it says circuit; $[\ldots]$ the first are effective for those who understand the words; the latter are effective for those who understand both the music and the words"; JOÃO IV, c.1650: 33-34; facsimile edition in RIBEIRO (ed.), 1965 .

15 See the complete edition of Rebelo's works in ALEGRIA (ed.), 1982, which also includes his eleven, more conventional pieces preserved in manuscript.

16 The first of which seem to have been CROTTI, 1608. 
TABLE 2. The structure of Rebelo's thirteen-voice Magnificat

\begin{tabular}{|l|l|}
\hline 1. Magnificat & Choir I (SSAT), Choir II (SATB), Choir III (A), and $b c$ \\
\hline 2. Et exsultavit & chant \\
\hline 3. Quia respexit & Choir I (SSAT), Choir II (SATB), Choir III (instr. S vocal A instr.T instr. B), instr. S, and $b c$ \\
\hline 4. Quia fecit & chant \\
\hline 5. Et misericordia eius & Choir III (instr. S vocal A instr.T instr. B), instr. S, and $b c$ \\
\hline 6. Fecit potentiam & chant \\
\hline 7. Deposuit potentes & Choir I (AT), Choir II (ATB), Choir III (A), instr. S, and $b c$ \\
\hline 8. Esurientes & chant \\
\hline 9. Suscepit Israel & Choir I (SSAT), Choir III (instr. S vocal A instr.T instr. B), instr. S, and $b c$ \\
\hline 10. Sicut locutus & chant \\
\hline 11. Gloria Patri & Choir I (SSAT), Choir II (SATB), Choir III (instr. S vocal A instr.T instr. B), instr. S, and $b c$ \\
\hline 12. Sicut erat & chant \\
\hline
\end{tabular}

However, João Lourenço Rebelo-also known as João Soares Rebelo-had a somewhat uncommon career among Portuguese composers of his time, as he never held any official duties, working freely as an amateur musician. He had became a choirboy at the Ducal Chapel in Vila Viçosa in 1624, when his older brother, Marcos Soares Pereira, was there admitted to serve as a chaplain-singer. Although he was six years younger than the future King João IV, then the Duke of Barcelos, Rebelo accompanied him in his music studies, under the guidance of the English (or Irish) composer Robert Turner (a former pupil of Géry de Ghersem), who at the time was chapel master at Vila Viçosa, and possibly also under the Carmelite Manuel Cardoso. In December 1640, along with his brother Marcos (who would be master of the Royal Chapel as of 1641), he went to Lisbon in the entourage of the duke, when the latter was made king after the restoring of the country's independence from the Spanish Habsburgs. At least two peerage books report that Rebelo "esteve doudo em Lisboa El Rei o mandou curar. Veio a seu juizo El Rei lhe deu o filhamento com duzentos mil r(eae)s de Juro e Erdade". ${ }^{17}$ Actually, in 1646 he was

17 "was insane while in Lisbon and the king gave orders for him to be taken care of. After he had recovered his senses, the king gave him the rank of a nobleman with an estate and interests of two hundred thousand reais"; BARRETO, Luís Gavião, Genealogia, P-Pm, Mss. 1601-1608, and CASTRO, Manuel de Araújo e, Nobiliário das famílias do Minho, copy with notes by Luís Gavião Barreto, $P$-Pm, Ms. 1590, as quoted in ALEGRIA (ed.), 1982, vol. 1: vii. granted a commandery of the Order of Christ and King João IV also dedicated him the Defensa de la mvsica moderna in testimony of friendship and appreciation; ${ }^{18}$ and, two days before he died on November 6, 1656, the king stated in the second codicil to his testament: "Mandei imprimir em Jtalia por conta de minha faz(end)a as obras de João Soares Rebello, faso lhe M(erce) daquella impressão e deixando uma duzia de volumes na minha livraria fara espalhar os maes por castella e por Jtalia e maes partes q(ue) lhe parecer". ${ }^{19}$ The collection, which includes thirty-three pieces dated between 1636 and 1653, was printed in Rome in 1657 in the workshop of Maurizio and Amadeo Balmonti, in seventeen partbooks with the title Joannis Laurentii Rabello Psalmi, tum Vesperarum tum Completarum. Item Magnificat, Lamentationes et Miserere (see Figure 2).

18 JOÃO IV, c.1650: 1-2 (letter of dedication).

19 "I have ordered in Italy, at the expenses of my treasury, the printing of the works of João Soares Rebelo; I make him an offer of this printing and leaving a dozen volumes in my library he will distribute the remaining in Castile and Italy, and other parts according to his judgment"; Testament of King João IV, P-Lant, Gaveta 16-2-17, available at <http://digitarq.dgarq.gov.pt/viewer?id=4185977> (accessed May $29,2014)$. The summary appended to the testament presents a slightly different reading: "Tenho mandado a Holanda imprimir as obras de João Soares Rebello da coal impressão lhe fasso merse Reservando p. ${ }^{a}$ a minha Livraria 20 Livros, e os outros os espalhará por Fransa, Jtalia, e Castella" (I have ordered in Holland the printing of the works of João Soares Rebelo, of which printing I make him an offer, reserving twenty copies to my library, and the other copies he will distribute in France, Italy, and Castile). 


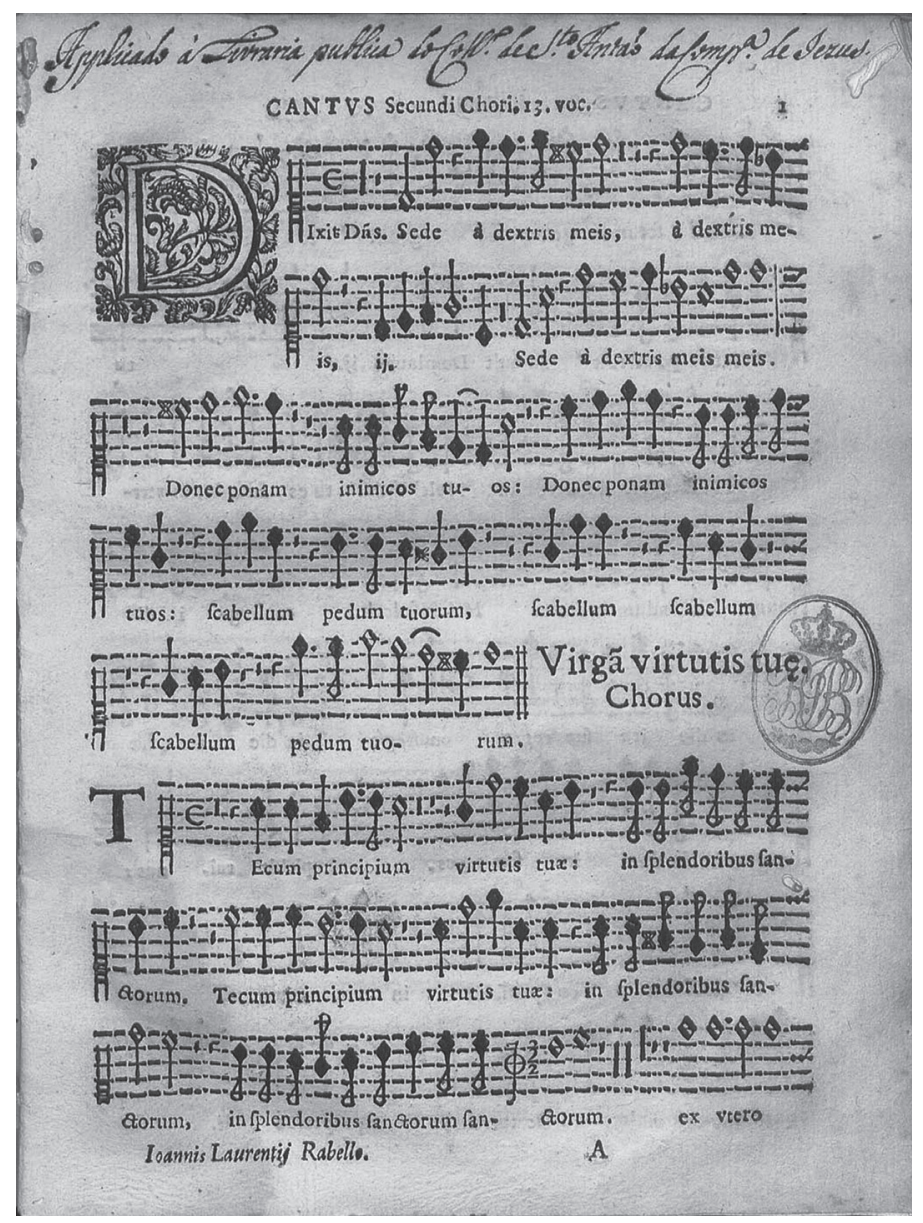

Figure 2. João Lourenço Rebelo, Psalmi, tum Vesperarum..., Rome, 1657, "Cantvs Secundi Chori” partbook, fol. 1r

But concertato music is not exclusive to Rebelo's 1657 print. Early examples of small-scaled concertato music are to be found for instance, in the eight sets of Magnificat verses "pera se cantarem ao orgão" (to be sung with the organ) included in Manuel Rodrigues Coelho's Flores de Mvsica, printed in Lisbon in 1620 (though compiled before 1617 and including older pieces), ${ }^{20}$ or the verses of the four Christmas responsories by Pedro da Esperança (died in 1660), added in manuscript $P$-Cug MM 18 , fols. 40v-48r,

20 COELHO, 1620; modern edition in KASTNER (ed.), 1961. which are written for one treble voice, three instruments "fagotillo", "Violim" and "Bayxão" (treble bassoon, violin and dulcian) - and a bass part for the organ (see Figure 3). ${ }^{21}$ And an example of a large-scaled concertato piece is the fifteen-voice setting of psalm Dixit Dominus, dated 1645, in manuscript $P$-Cug MM 228, fols. $14 \mathrm{v}-21$ r, whose parts are arranged as following: Choir I (SA), Choir II (instr. S instr. A instr. T instr. B), Choir III (SATB), Choir IV (SAT), Choir V

21 Modern edition in ALVARENGA (ed.), 1989. On manuscript P-Cug, MM 18, see REES, 1995: 195-200. 
(SA), and $b c \cdot{ }^{22}$ However, in the realm of sacred music (that is, excepting the vilancico genre), small-scale, four- to six-- part and double-choir vocal writing are much more common in late-sixteenth- to mid-seventeenth-century Portugal. ${ }^{23}$

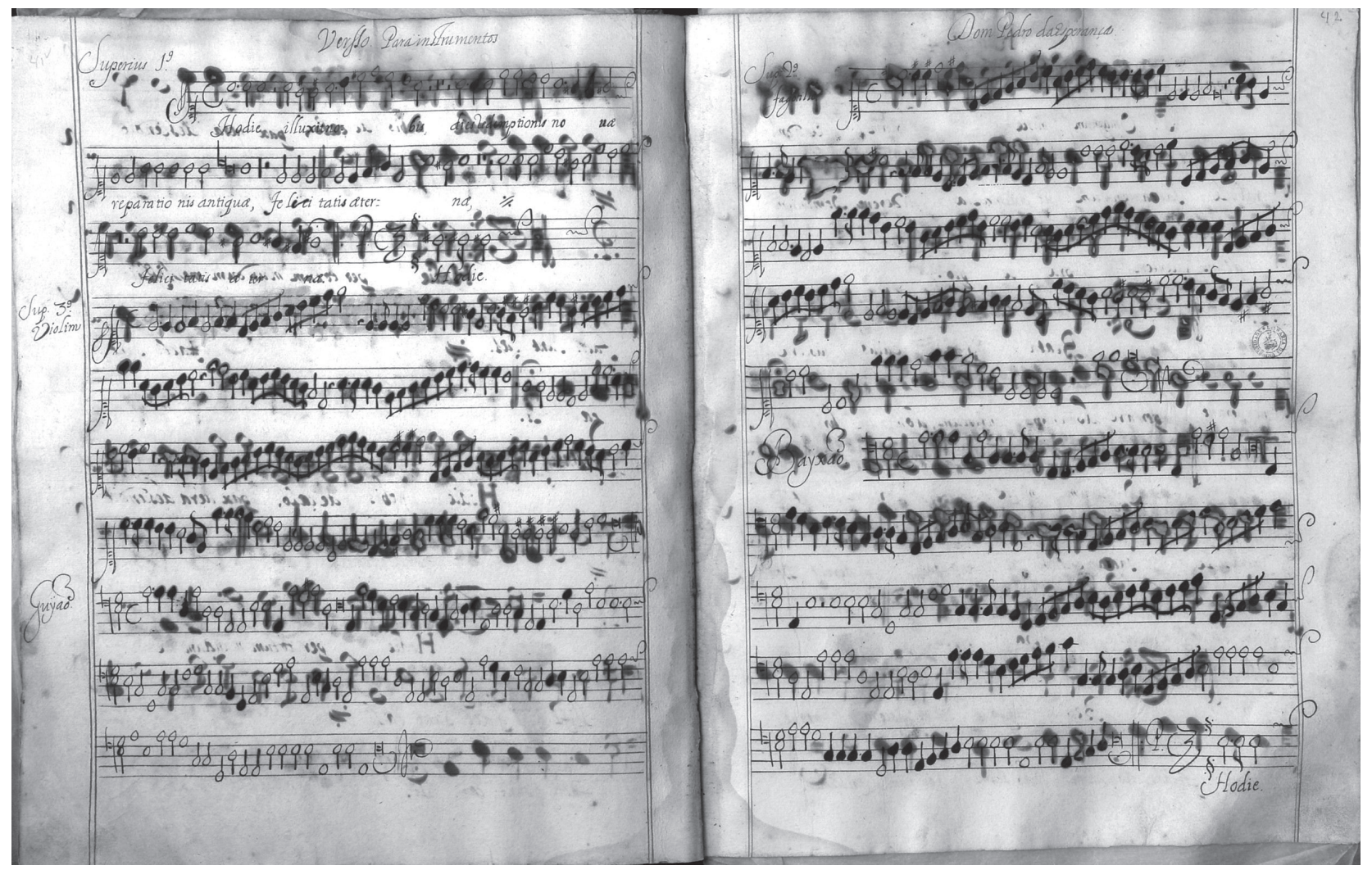

Figure 3. P-Cug MM 18, fols. 41v-42r: Pedro da Esperança, Versso Para instrumentos from Responsory II for Christmas

The first print by a Portuguese composer to include polychoral music were the Opvscvla by Duarte Lobo (died in 1646), issued in Antwerp in 1602 by the workshop of Christoffel Plantin's eldest son-in-law, Jan Moerentorf. These were printed in eight quarto partbooks, including twenty-one pieces for four to eleven voices in three choirs. Opening the collection, there is a complete set of eight-voice, double-choir

22 On this particular piece, see BRITO, 1989: 57-58. On manuscript $P$-Cug, MM 228, see BRITO (ed.), 1983: vii-viii. responsories for Christmas (see Figure 4). ${ }^{24}$ The polyphonic responsory either intended for Christmas or the Triduum offices has emerged in Portuguese manuscript sources in the mid-1570s, as a consequence of the adoption of the Tridentine breviary. As a genre, it can be briefly characterised for always adopting the structure of the text, which is set complete in a more or less straightforward fashion resulting in an $\mathrm{aBcB}$ form, ${ }^{25}$ most often with a prevailing homophonic texture for

23 On polychoral repertories in Portugal, see ABREU, 2002; see also CASTILHO, 2009.

24 The complete title of Lobo's print reads: Opvscvla: Nataliae Noctis Responsoria quaternis vocibus \& octonis. Missa Eiusdem Noctis octonis vocibus. Beatae Mariae Virginis Antiphonae octonis etiam vocibus. Eiusdem Virginis Salve choris tribus \& vocibus vndenis, Antwerp, ex Officina Plantiniana, Apud Ioannem Moretum, 1602; no set of the eight partbooks is known to have survive complete.

$25 \mathrm{Or}$ an $\mathrm{aBcBd}(\mathrm{a}) \mathrm{B}$ form if the doxology is to be sung, as in the first, third, sixth and eight responsories for Christmas. 
the respond and especially the repetendum, and imitative for the verse, which as a rule is written for fewer voices, the whole setting having no relation with the chant respective to its text and no cantus firmus whatsoever (contrary to the polyphonic responsories for the Dead, which had appeared much earlier in Spanish and Portuguese sources). ${ }^{26}$

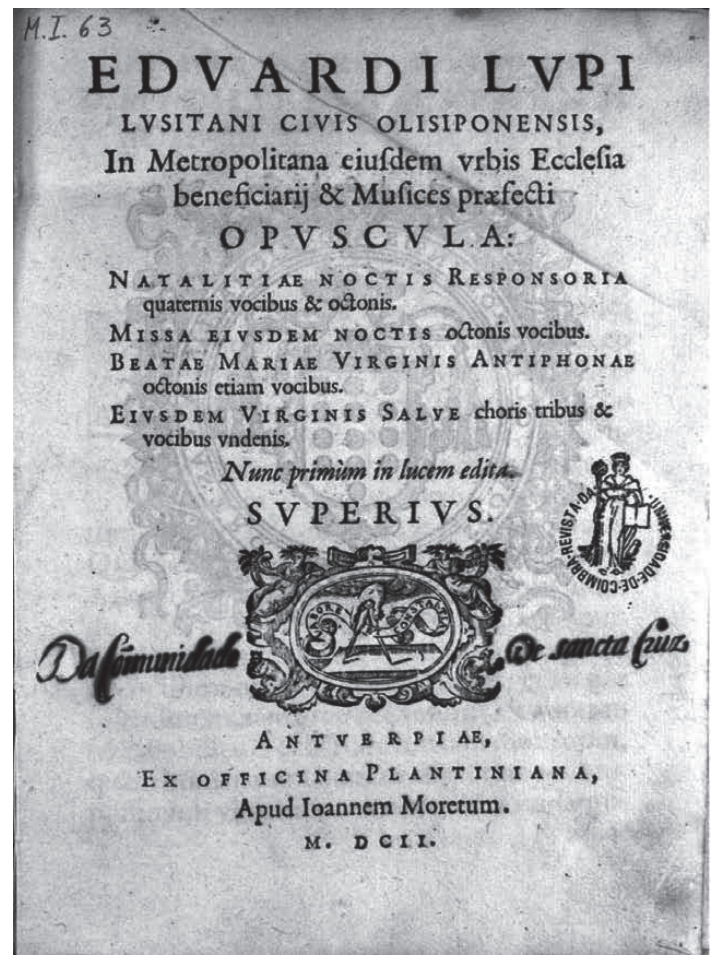

Figure 4. Duarte Lobo, Opvscvla..., Antwerp, 1602, Svperivs partbook, title-page
Fernando de Almeida's set of responsories for Maundy Thursday is a good example of the aesthetic and compositional concepts expressed in King João IV's brief treatise. ${ }^{27}$ The overall polychoral writing is typical of the late sixteenth century, as displayed in the set of eight-voice Christmas responsories by Duarte Lobo, just referred to: the two choirs act in an independent way for most of the time, interacting in antiphonal style and merging into one eight-voice choir for more emphatic moments, particularly at the final cadences in the main sections and subsections. Although most of the phrases are set homophonically, there are segments of a refined contrapuntal texture. Lobo always uses the same voice and clef combination for the two choirs (SATB+SATB). On the contrary, except for Responsory I, Almeida uses a higher and a lower choir (SSAT+SATB). Both composers, Lobo and Almeida, pay continuous attention to the text at the structural level-as described in the Defensa de la mvsica moderna-but Almeida is especially attentive to its prosodic and rhetorical implications.

As examples of proprietas of music writing, in line with King João IV's 1649 treatise, we can point out the opening of Responsory II, where the words "tristis" (sad) and "mortem" (death), besides being scored for full texture, use longer note values than the remaining text. Moreover, the unexpected progression from $B$ flat major to $D$ major on "mortem" (with a leap from $B$ flat to $F$ sharp in the bass) stresses the symbolism of the word (see Example 1); also, at the end of the respond of Responsory IV, there is a sudden change of register as the high choir sings "qui per osculum ad implevit" (who by a kiss accomplished) leaving to the lower choir alone the last word, "homicidium" (murder) (see Example 2).
26 On the polyphonic responsory in late-sixteenth- and earlyseventeenth-century Portuguese manuscripts, see ALVARENGA, 2005, vol. 1: 54-57.
27 Modern edition in VAZ (ed.), forthcoming. 

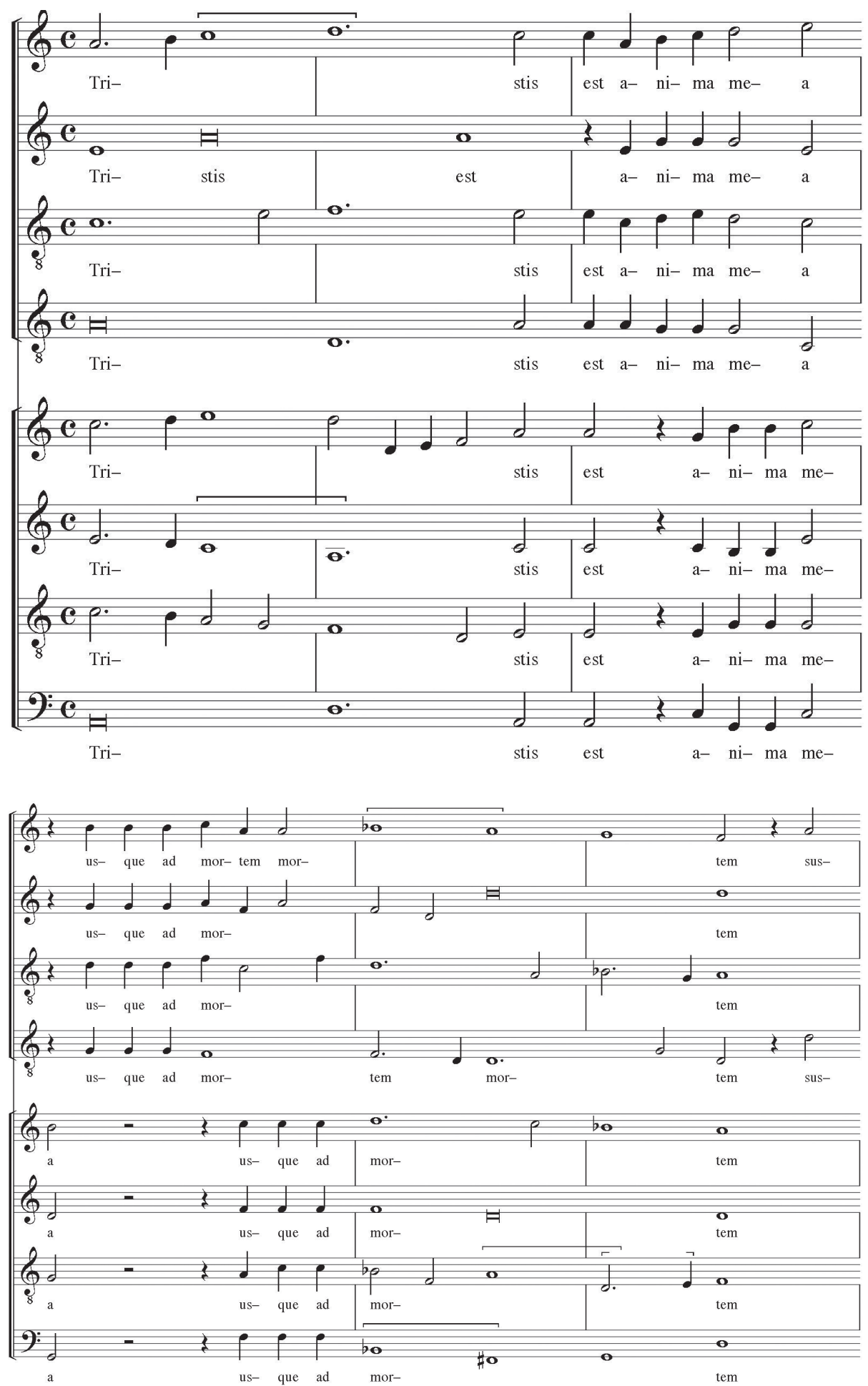

Example 1. Fernando de Almeida, Responsory II for Maundy Thursday, bb. 1-6 


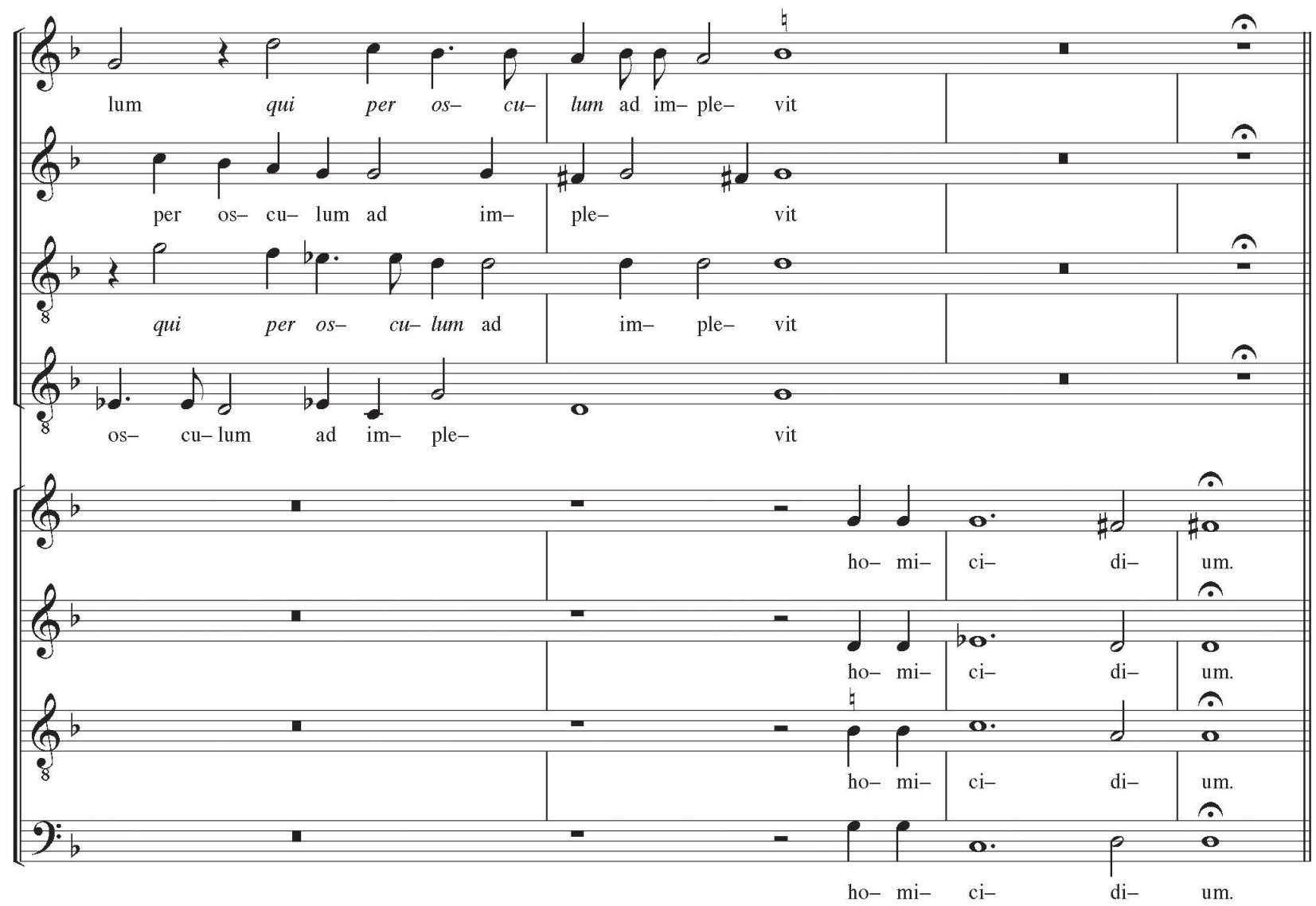

Example 2. Fernando de Almeida, Responsory IV for Maundy Thursday, bb. 11-14

There are also striking instances of use of musicalrhetorical gestures. The text "Vos fugam capietis" (Ye shall take flight) in the repetendum of Responsory II is treated in close eight-voice imitation and using fusae in descending stepwise motion, thus illustrating the word "fugam" in its double sense of "flight" and "fugue" (see Example
3). A similar situation can be found in the repetendum of Responsory VIII on the word "festinat" (hurry), this time with an ascending motif. The texture is also different, since the motif implicates pairs of voices dialoguing within the same choir and from one choir to the other (see Example 4). 


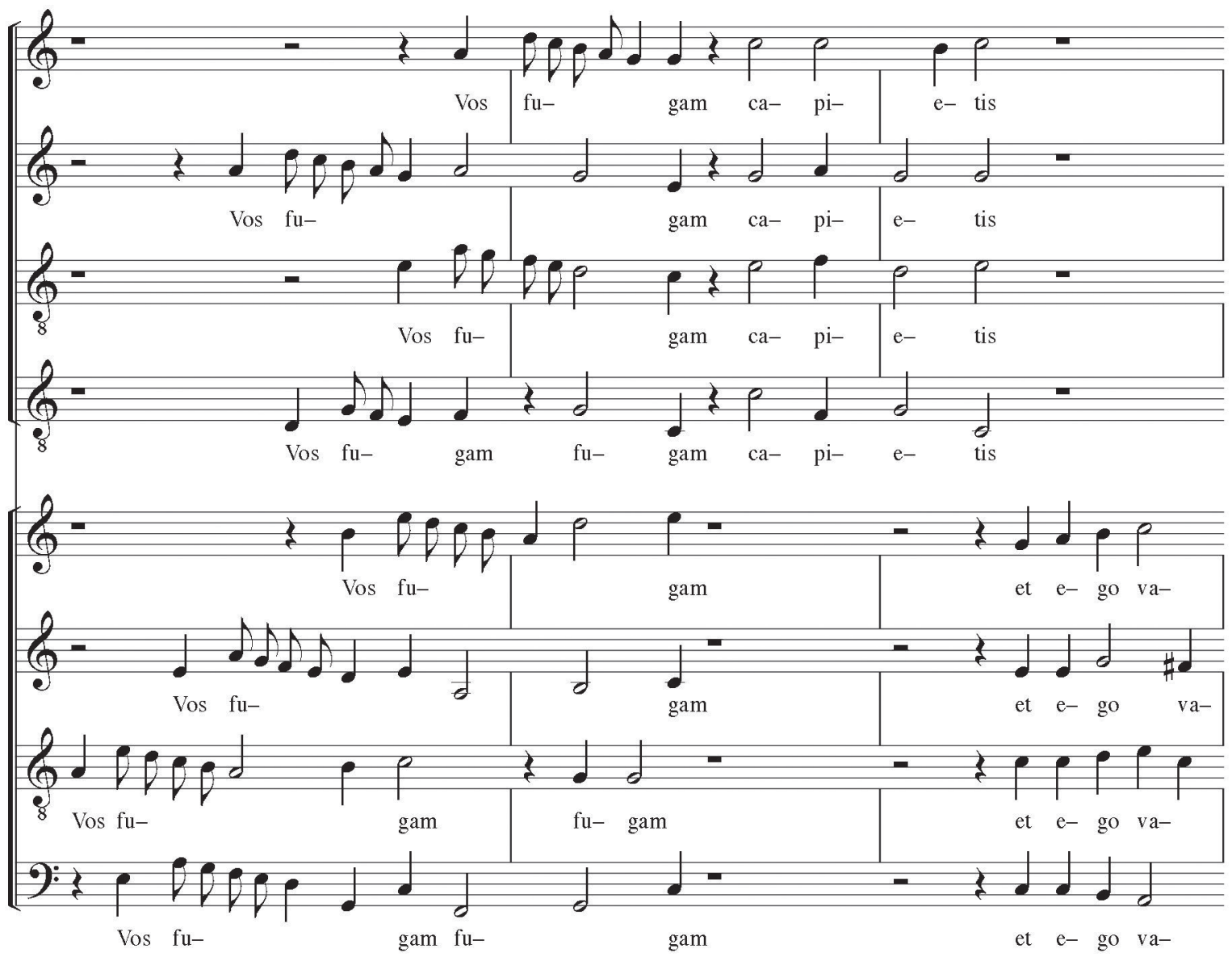

Example 3. Fernando de Almeida, Responsory II for Maundy Thursday, bb. 16-18 


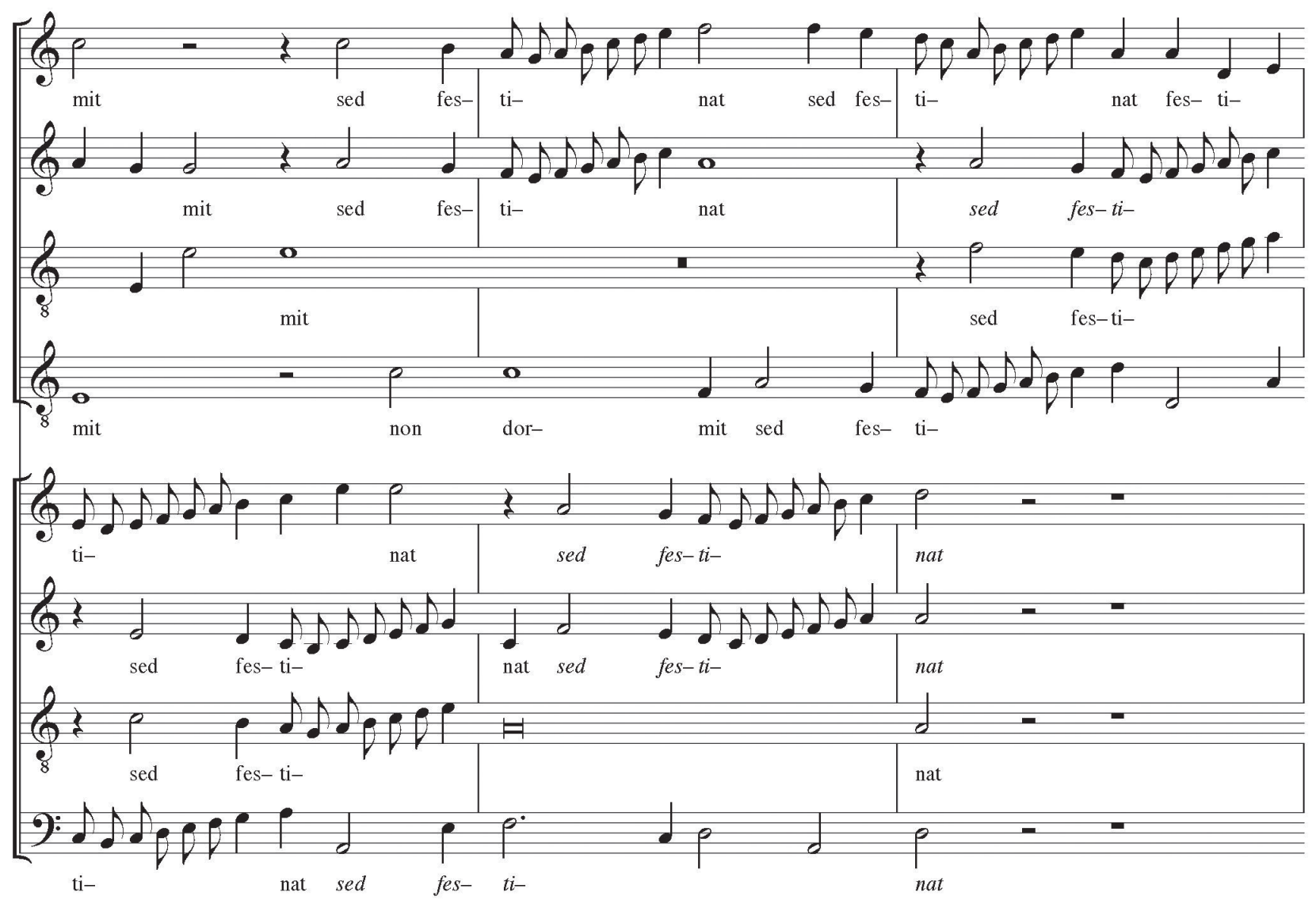

Example 4. Fernando de Almeida, Responsory VIII for Maundy Thursday, bb. 14-16

These last two examples reflect a relatively common practice in Mannerist music. A much more innovative - and indeed Baroque - procedure can be found at the end of the repetendum of Responsory IV. Here, the words "se suspendit" (hung himself) are delivered in a declamatory way, with all the syllables set in semiminimae, and always followed by a rest. This surprising effect is even more so in the final cadence, where the words are set in the same way and the music is abruptly suspended after the last note, as if suggesting Judas Iscariot hanging from the fig tree (see Example 5). 


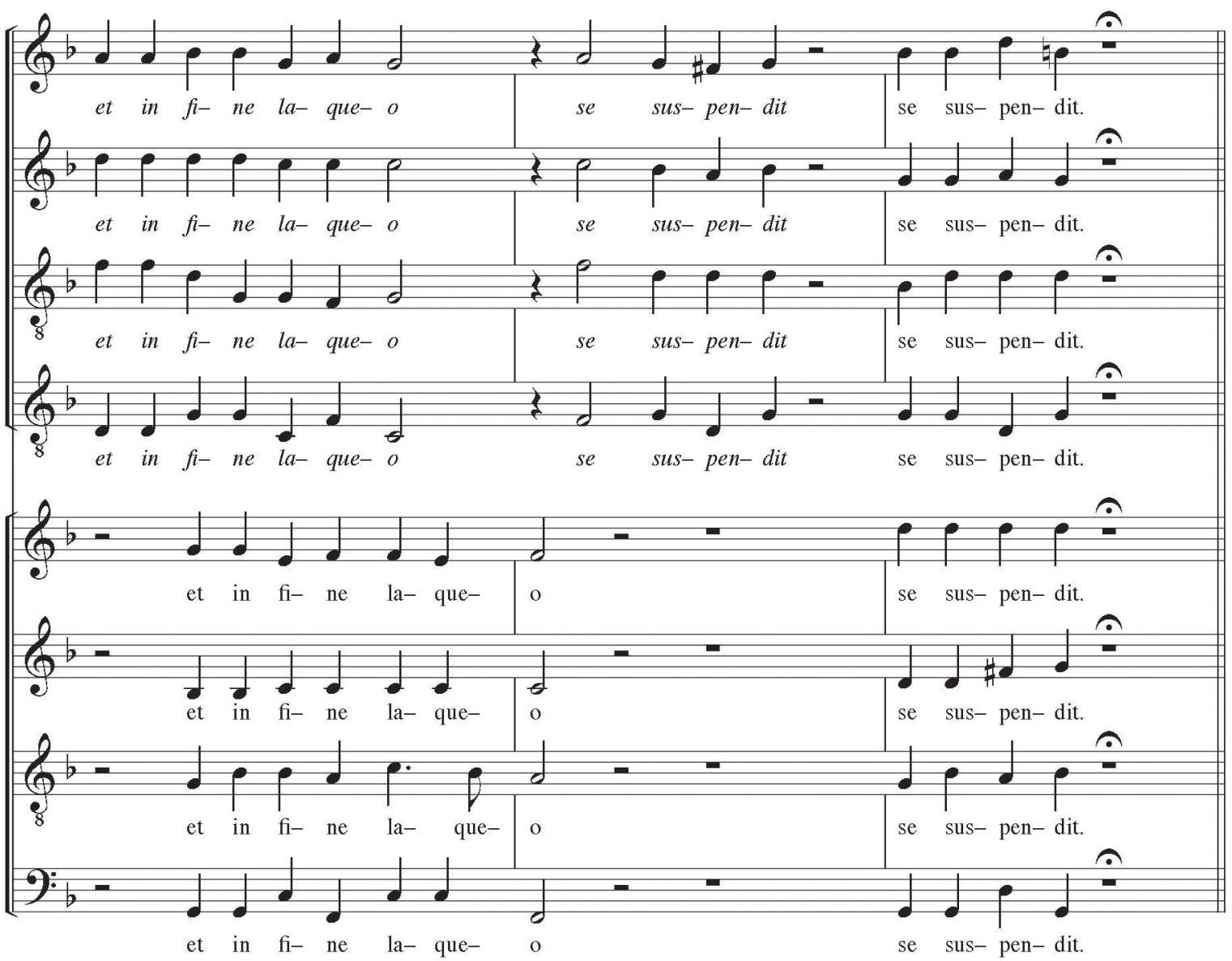

Example 5. Fernando de Almeida, Responsory IV for Maundy Thursday, bb. 21-23

While dealing with the central issue of the relation between text and music, the small treatise by King João IV also touches matters of performance practice nature, namely dynamics, in a way that redundancy of text and musical gesture is further amplified:

El compositor deve acommodar siempre la musica a la letra [...] ordonandola con varias diferencias [...] de modo que oyendo el compositor cantar un mottete que diga (pongo por caso) Clamavi, començando la voz que entra, en los terminos altos, acomodandose con la letra, conoce que por amor de la letra entra gritando. ${ }^{28}$

28 "The composer must always match the music with the text [...] by organizing it with a variety of procedures [...] in such a way that when the composer hears a motet sung which for instance, contains the word Clamavi in the first voice to enter, in the higher register, this should be screamed, out of love for the text"; JOÃO IV, c.1650: 32-33.
Another aspect of the performance of late-Mannerist and early-Baroque music-and a most controversial one-is the placement of semitones, an issue similar in practice to sixteenth-century musica ficta (that is, the introduction during performance of unwritten chromatic alterations according to a set of commonly accepted, though variable rules). The addition of accidentals is not systematic in most of seventeenth-century manuscript sources. Even when the tendency to alter certain notes in order to create a leading note effect was a deeply rooted practice, relatively few accidentals appear especially in manuscript music, precisely in situations (such as cadences) where the need for the alteration is obvious. The modern performer, besides comparing the whole of a musical work with the (often few) situations where alterations are expressly indicated, should bear in mind the growing conscience of the attraction to certain tonal centres, which was quite common in the seventeenth 
century, but always be cautious for not to subvert intended or potential expressive effects.

Examples of lacking accidentals can be seen for instance, in the opening section of Responsory I, where the first cadence (on the word "Patrem") certainly call for a major third in the last chord, even though the following chord has a minor third (see Example 6) ${ }^{29}$ Close juxtaposition of major and minor forms of a chord often implying melodic chromaticism and different types of crossrelation-including vertical major-minor clashes-were indeed favoured expressive devices, which continued to be explored until the late seventeenth century. ${ }^{30}$

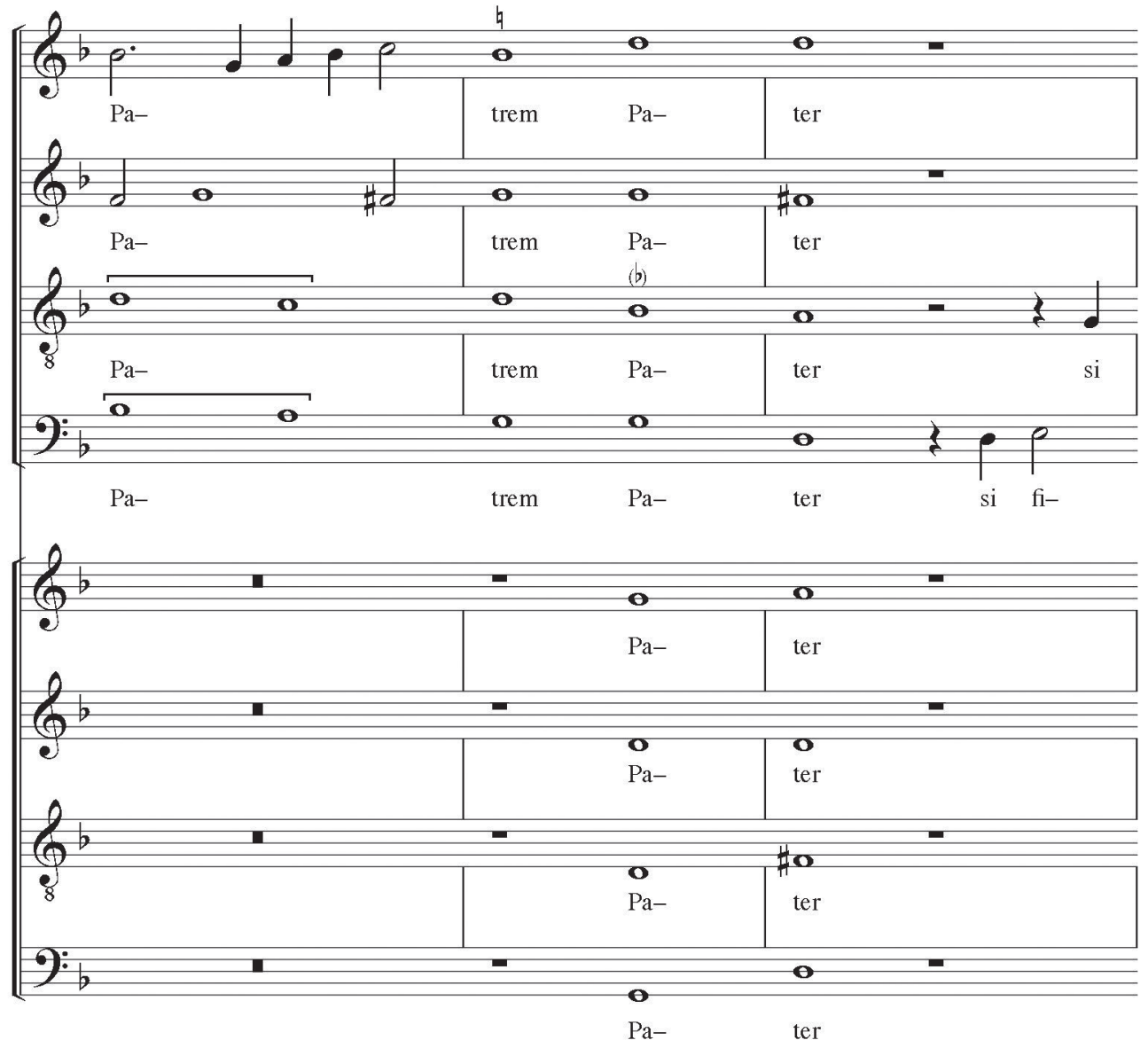

Example 6. Fernando de Almeida, Responsory I for Maundy Thursday, bb. 4-6

29 This solution was adopted in the recent recording of this work, in VAZ (dir.), CD 2011, but not in an older recording, in REES (dir.), CD 1996.

30 See for instance, regarding Portuguese seventeenth-century repertory, SILVA, 1/1 (Lisbon, 2014): 67-82. 
There are, however, situations where the juxtaposition of voices should have raised different solutions depending on the period during which the piece was performed. For instance, in the second phrase of the respond of Responsory VI ("vae illi..."), it seems obvious that the $F$ in Cantus III should be altered, given not only its cadencial context but also the presence of a $F$ sharp in Altus II. But in the subsequent entry of the high choir there are two $F$ naturals superposed to the previous chord. Up to the late seventeenth century, these would probably not be altered, giving rise to a "mi contra fa" situation, which the spatial separation of the two choirs will possibly mitigate (see Example 7). In the eighteenth century, however, as suggested in examples of reworking of late-sixteenth- and early-seventeenth-century polyphony contained in the 1735-1736 series of choirbooks from Vila Viçosa, ${ }^{31}$ all $F$ will be sharped, including those in the entry of the high choir. ${ }^{32}$

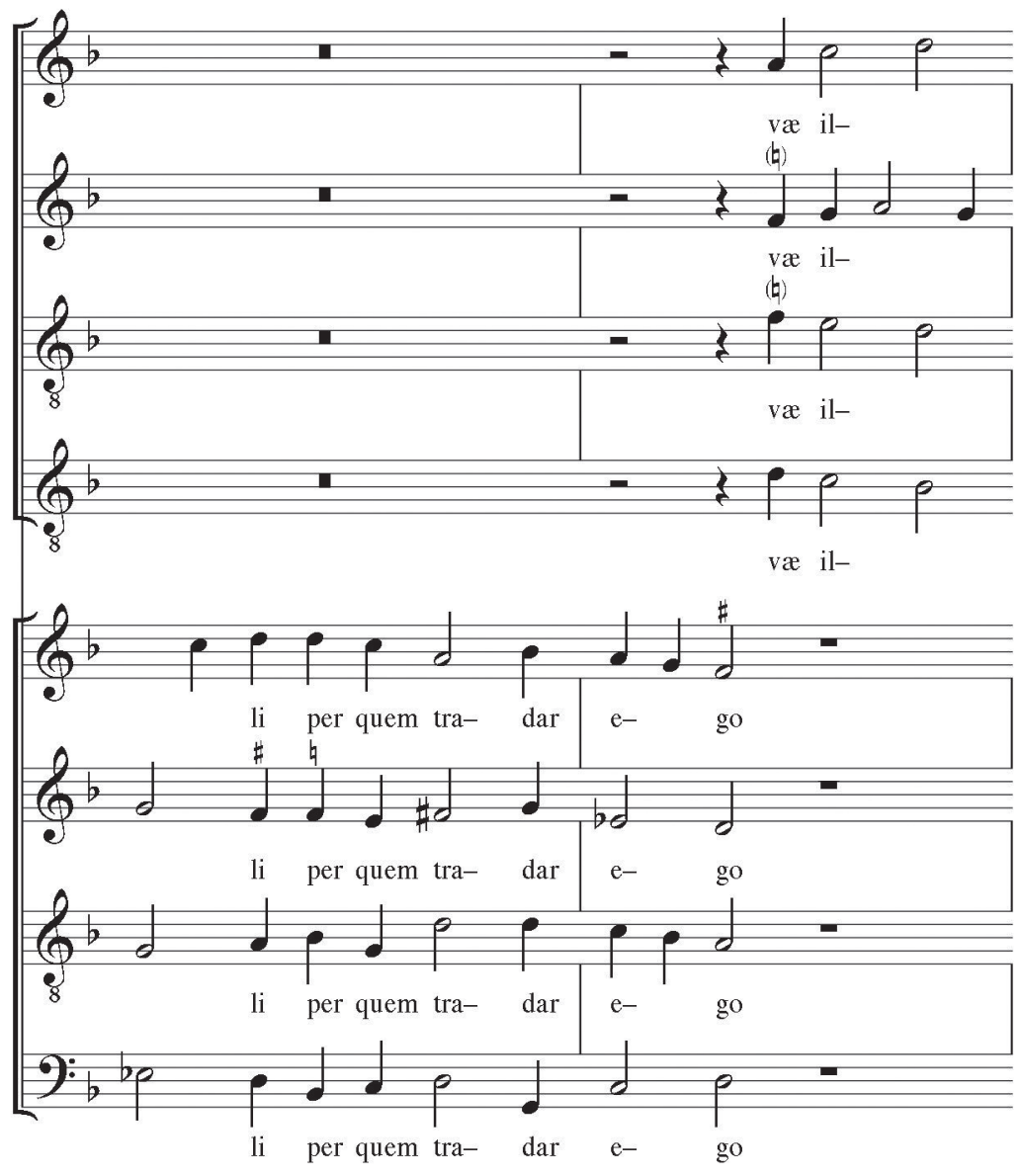

Example 7. Fernando de Almeida, Responsory VI for Maundy Thursday, bb. 4-5

31 For an example of such reworking, see ALVARENGA, 8/2 (Cambridge, 2011): 186-188, with an edition of the pieces at 206-214.

32 A compromise, or intermediate solution, would be to shorten the cadencial major chord in the lower choir, in order to avoid superposition with the minor chord in the high choir, so producing a successive cross-relation instead of a simultaneous one. This was, in fact, the solution adopted in VAZ (dir.), CD 2011. 
The ingenuity of Fernando de Almeida's style is particularly prominent in these eight-voice responsories, where the discourse is engendered by the juxtaposition of differentiated, if not contrasting, musical ideas, which are tossed back and forth from one choir to the other, and which reflect or imitate musically the varied meanings expressed in the texts: there is a constant alternation of homophonic sections with unexpected chord progressions or sections with a contrapuntal texture that incorporate suspensions and dissonances, or vocalises that shift rapidly from one voice to another, and declamatory passages, sometimes in a rapid parlante style. Naturalistic processes like the significant level of redundancy between text and musical gesture and the consistent integration of ornament within the melodic structure are essentially Baroque features, though within the mould of the stile antico of Iberian Mannerist tradition, of which, as seen, Fernando de Almeida is at the same time both heir and innovator.

\section{Bibliography}

\section{Manuscripts}

Barreto, Luís Gavião, Genealogia, P-Pm, Mss. 1601-1608

Castro, Manuel de Araújo e, Nobiliário das famílias do Minho, copy with notes by Luís Gavião Barreto, P-Pm, Ms. 1590

Cruz, Francisco da, Bibliotheca Lusitana, P-La, Ms. 51-V-50

Process against Fernando de Almeida, P-Lant, Tribunal do Santo Ofício, Inquisição de Lisboa, Proc. 11047

Testament of King João IV, P-Lant, Gaveta 16-2-17

\section{Early Prints}

Coelho, Manuel Rodrigues, Flores de Mvsica: pera o instrvmento de Tecla, \& Harpa, Lisbon, Pedro Craesbeeck, 1620

Crotti, Archangelo, Il Primo Libro de' Concerti Ecclesiastici, Venezia, Giacomo Vincenti, 1608

João IV, Defensa de la mvsica moderna, contra la errada opinion del Obispo Cyrilo Franco, 1649, [Lisbon (?), Paulo Craesbeeck (?), c.1650]

Lobo, Duarte, Opvscvla: Nataliae Noctis Responsoria quaternis vocibus \& octonis. Missa Eiusdem Noctis octonis vocibus. Beatae Mariae Virginis Antiphonae octonis etiam vocibus. Eiusdem Virginis Salve choris tribus \& vocibus vndenis, Antwerp, ex Officina Plantiniana, Apud Ioannem Moretum, 1602

Machado, Diogo Barbosa, Bibliotheca Lusitana, vol. 2, Lisbon, Officina de Ignacio Rodrigues, 1743
Primeira parte do Index da Livraria de Mvsica do muyto alto, e poderoso Rey Dom Ioão o IV. Nosso Senhor, Lisbon, Paulo Craesbeeck, 1649

\section{Modern Publications}

Abreu, José, Sacred Polychoral Repertory in Portugal, ca. 1580-1660, Ph.D. dissertation, University of Surrey, 2002

Alegria, José Augusto (ed.), João Lourenço Rebelo (16101661): Psalmi tum Vesperarum, tum Completorii. Item Magnificat Lamentationes et Miserere, 4 vols. (Portugaliae Musica, 39-42), Lisbon, Fundação Calouste Gulbenkian, 1982

Alvarenga, João Pedro d', "Corrigendum", EighteenthCentury Music, 9/2 (Cambridge, 2012): 295

Alvarenga, João Pedro d', “To Make of Lisbon a New Rome': The Repertory of the Patriarchal Church in the 1720s and 1730s", Eighteenth-Century Music, 8/2 (Cambridge, 2011): 179-214

Alvarenga, João Pedro d', "The Debate on Musical Aesthetics around 1600 and the Defensa de la mvsica moderna by King João IV (1649)", in João Pedro d' Alvarenga and Manuel Pedro Ferreira (eds.), 'New Music' 14001600: Papers from an International Colloquium on the Theory, Authorship and Transmission of Music in the Age of the Renaissance (Lisbon-Évora, 27-29 May 2003), Lisbon and Évora, CESEM, Centro de História da Arte e Investigação Artística and Casa do Sul Editora, 2009: 239-250

Alvarenga, João Pedro d', Polifonia portuguesa sacra tardo-quinhentista: estudo de fontes e edição crítica do Livro de São Vicente, manuscrito P-Lf FSVL $1 P / H$ 6, 2 vols., Ph.D. dissertation, Universidade de Évora, 2005

Alvarenga, João Pedro d' (ed.), Dom Pedro da Esperança (+1660): Four Christmas Responsories (Mapa Mundi, A/76), Lochs, Vanderbeek \& Imrie, 1989

Brito, Manuel Carlos de, "Partes instrumentais obrigadas na polifonia vocal de Santa Cruz de Coimbra”, in Manuel Carlos de Brito, Estudos de História da Música em Portugal, Lisbon, Editorial Estampa, 1989: 55-63

Brito, Manuel Carlos de (ed.), Vilancicos do século XVII do Mosteiro de Santa Cruz de Coimbra (Portugaliae Musica, 40), Lisbon, Fundação Calouste Gulbenkian, 1983

Castilho, Maria Luísa Correia, As obras de Manuel de Tavares e o desenvolvimento da policoralidade na polifonia portuguesa do século XVII, Ph.D. dissertation, Universidade de Évora, 2009 
Cota, Cristina Maria de Carvalho, A Música no Convento de Cristo em Tomar (desde finais do século XV até finais do século XVIII, Master thesis, Faculdade de Ciências Sociais e Humanas, Universidade Nova de Lisboa, 2007

Kastner, Macario Santiago (ed.), Manuel Rodrigues Coelho: Flores de Musica pera o instrumento de tecla \& harpa, 2 vols. (Portugaliae Musica, 1-2), Lisbon, Fundação Calouste Gulbenkian, 1961

Nery, Rui Vieira, The Music Manuscripts in the Library of King D. João IV of Portugal (1604-1656): A Study of Iberian Music Repertoire in the Sixteenth and Seventeenth Centuries, Ph.D. dissertation, University of Texas at Austin, 1990

Nery, Rui Vieira (ed.), A música no ciclo da "Bibliotheca Lusitana", Lisbon, Fundação Calouste Gulbenkian, 1984

Rees, Owen, Polyphony in Portugal c. 1530 - c. 1620: Sources from the Monastery of Santa Cruz, Coimbra, New York and London, Garland, 1995

Ribeiro, Mário de Sampaio (ed.), El-Rei D. João IV: Defensa de la mvsica moderna contra la errada opinion del
Obispo Cyrilo Franco [including a complete facsimile of the original print], Coimbra, Universidade, 1965

Silva, Pedro Sousa, "Musica ficta and Implied Chromatic Inflexions in the Music of Estêvão Lopes Morago", Revista Portuguesa de Musicologia, new series, 1/1 (Lisbon, 2014): 67-82, at <http://rpm-ns.pt/index.php/ $\mathrm{rpm} /$ issue/view/4 >

Vaz, João (ed.), Frei Fernando de Almeida: Responsórios de Quinta-Feira Santa; Missa ferial, Lisbon, CESEM, forthcoming

\section{Recordings}

Rees, Owen (dir.), A Capella Portuguesa, Holy Week at the Chapel of th Dukes of Braganza, CD Hyperion, CDA66867, 1996

Vaz, João (dir.), Capella Patriarchal, Fr. Fernando de Almeida: Missa ferial; Responsórios de Quinta-Feira Santa, CD Althum, 004, 2011

Recibido: 29.04.2014

Aceptado: 02.10.2015 